Pak. j. sci. ind. res. Ser. B: biol. sci. 2019 62B(1) 33-38

\title{
Molecular and Morphological Characterisation of Pakistani Guava Germplasm
}

\author{
Shariq Mahmood Alam**, Armghan Shahzad ${ }^{\mathrm{b}}$, Sania Begum ${ }^{\mathrm{b}}$, Ahmad Sattar Khana and \\ Muhammad Arshad Ullah ${ }^{\mathrm{c}}$ \\ ${ }^{a}$ Institute of Horticultural Sciences, University of Agriculture, Faisalabad, Pakistan \\ ${ }^{b}$ National Institute for Genomics and Advanced Biotechnology, Islamabad, Pakistan \\ ${ }^{c}$ Land Resources Research Institute, NAR Centre, Park Road, Islamabad-45500, Pakistan
}

(received January 16, 2017; revised January 12, 2018; accepted February 21, 2018)

\begin{abstract}
The study was conducted to characterise genetic and morphological characters of eight guava genotypes (Rangwala Gola, Saddabahar, Saddabahar Barhi Surahi, Larkana, Kohati, Special Amrod, Moti Surahiwala and Amrod Barhi Surahi) at National Agricultural Research Centre, Islamabad during 2016. Completely randomized design (CRD) was followed with three replications. In order to study the genetic diversity in these varieties, the randomly amplified polymorphic DNA (RAPD) technique was performed for molecular characterisation. For morphological characterisation, the morphological descriptors were used. The clustering tree was produced from the results of the seven primers and morphological descriptors through which the genetic and morphological diversity were observed. From the results obtained through molecular markers and morphological parameters, among these guava varieties immense variation in the genetical make up and physiological appearance was examined. The clustering tree of similarity among the eight guava varieties showed different results in each clustering tree of genetical and morphological characteristics.
\end{abstract}

Keywords: morphological diversity, molecular marker, polymerase chain reaction, clustering tree, guava genotypes

\section{Introduction}

The guava (Psidium guajava L.) is a member of the Myrtaceae family with $(2 \mathrm{n}=22)$ consists of fruiting trees and shrubs which has more than 150 species (Jaiswal and Jaiswal, 2005), of which 59 are present in Brazil and 10 are present in Espírito Santo. Guava is being grown all over the sub-tropical and tropical world due to its high dietary value and good flavour. It is an important and one of the most nutritious fruit plant of tropical and subtropical regions and contains high amounts of vitamins A, B1 (thiamin), B2 (riboflavin) and $\mathrm{C}$. It is a rich source of vitamin $\mathrm{C}$ (ascorbic acid). Vitamin $\mathrm{C}$ contents of guava fruit are four times higher than that of citrus (Luanda et al., 2006; Rahman et al. 2003). The leaves of guava have been used for curing diarrhoea and dysentery. But unfortunately, in Pakistan people utilize guava just for taste and mostly unfimilair with its nutritional value.

There are many factors affecting the yield of the guava fruits in the regions and its quality and productivity are generally limited by soil salinity and poor soil fertility (Ahmed and Qamar, 2004), amongst other abiotic

*Author for correspondence;

E-mail: m.smahmoodisb@gmail.com (drought, frost, rain) and biotic (nematodes, insect/pests and diseases) factors. The major factors affecting the quality and productivity of guava in Pakistan, presently are the fruit flies which cause the major yield loss in guava crop and its biological control is difficult (Mumford and Norton, 1984). Guava breeding could help in enhancing the crop productivity, fruit quality and also control the biotic and abiotic factors. However, the first step in the characterisation of the genetic variability in the germ lines propagated in order to detect those trees that can be employed as parent material for crop improvement. Phenotypic and productive variability have been found in most orchards from where the germplasm of different guava varieties is collected. The increase in consumption both as a table fruit and natural juices is a worldwide trend; supplementary guava is getting popular over care, health and aesthetics worldwide in the recent years. Kidaha et al. (2015) has studied the morphological characterisation of guava landraces from western and coastal landraces using 13 qualitative and 2 quantitative descriptors. Root descriptors between the landraces in the two regions did not show any differences, while the leaf, fruit, branching of stem showed variations. Leaf shape varied, 
being oblong, trapezoidal, elliptical and ovate. Branching habits were axial, erect or irregular.

Randomly amplified polymorphic DNA (RAPD) is a technique which is based on the polymerase chain reaction (PCR) markers, requiring only tiny amount of genomic DNA and does not require expensive material as in molecular technique like radioactive material (Malabadi et al., 2006). There are many plants reported in which the successful application of RAPD technique is used to assess the genetic diversity of different plants. The RAPD markers in particular, have been successfully used to determine genetic diversity among species in tropical and subtropical forest plants (Akbar et al., 2011; Elmeer and Almalki, 2011; Wangsomnuk et al., 2011; Parkash and Staden 2008; Enjalbert et al., 1999). Molecular markers are the pre-breeding and advanced tool for the successful assessing of the characterisation and evaluation of genetic diversity among different plant species and population (Bakhat et al., 2012). The popularity of PCR is primarily due to its apparent simplicity and high probability of success. Unfortunately, because of the need for DNA sequence information, PCR assays are limited in their application. The discovery that PCR with random primers can be used to amplify a set of randomly distributed loci in any genome facilitated the development of genetic markers for a variety of purposes. The main reason for the success of RAPD analysis is the gain of a large number of genetic markers that require small amounts of DNA without the requirement for cloning, sequencing or any other form of the molecular characterisation of the genome. Keeping all these factors in view, a study was designed to examine genetic and morphological diversity of eight different guava genotypes grown in Pakistan.

\section{Materials and Methods}

Plant materials. Eight guava genotypes were selected from the orchard of National Institute of Genomics and Advanced Biotechnology (NIGAB), National Agriculture Research Centre (NARC), Islamabad, Pakistan. The plant samples with complete juvenility were selected. For the morphological studies three plants of same variety were selected and average of these three plants were used as the final reading. The names of varieties and their abbreviations are Rangwala Gola (RG), Saddabahar (SB), Saddabahar Barhi Surahi (SBBS), Larrkana, Kohati, Special Amrood (SA), Moti Surahi Wala (MSW) and Amrod Barhi Surahi (ABS).
DNA extraction and quantification. The fresh epical meristem from eight varieties was used to conduct and extraction of DNA. To extract DNA, the modified CTAB method described by Doyle and Doyle (1990) was followed. The DNA extraction was done with great care to minimize the error chances. The mercaptoethanol was used as a replacement of liquid nitrogen. The DNA pellets were dissolved into $100 \mu \mathrm{L}$ of deionized water in each sample, respectively. The samples were incubated at $4{ }^{\circ} \mathrm{C}$ for at least $2 \mathrm{~h}$ till the DNA pellets were completely dissolved into the deionized water. Samples were stored at $4^{\circ} \mathrm{C}$ until the PCR was started. Actual DNA concentration was quantified through the biospecnano instrument (Table 1) and the dilutions were prepared for further PCR processes (Table 2).

Polymerase chain reaction (PCR). In order to comportment through polymerase chain reaction (PCR) the $20 \mu \mathrm{L}$ of reaction volume was used in which the $1.5 \mu \mathrm{L}$ of template DNA and $18.5 \mu \mathrm{L}$ of master mixed was used. To make master mix following reagents were used $10 \times$ PCR buffer, $\mathrm{MgCl}_{2}$, dNTP mix, Primer and Taq polymerase of fermentase. The reaction volume was set in the PCR try and the PCR amplification was carried out in an automated applied bio-systems thermal cycler (variety 96 well) at $94{ }^{\circ} \mathrm{C}$ for 4 min, followed by 45 cycles each consisting of three steps; first step

Table 1. Actual DNA concentrations in the samples extracted

\begin{tabular}{llll}
\hline \hline $\begin{array}{l}\text { Sample } \\
\text { no. }\end{array}$ & $\begin{array}{l}\text { DNA concen- } \\
\text { tration }(\eta \mathrm{g} / \mu \mathrm{L})\end{array}$ & $\begin{array}{l}\text { Sample } \\
\text { no. }\end{array}$ & $\begin{array}{l}\text { DNA concen- } \\
\text { tration }(\eta \mathrm{g} / \mu \mathrm{L})\end{array}$ \\
\hline 1 & 1731.26 & 5 & 1877.30 \\
2 & 2420.31 & 6 & 348.120 \\
3 & 3254.67 & 7 & 3708.32 \\
4 & 2268.51 & 8 & 1574.39 \\
\hline \hline
\end{tabular}

Table 2. DNA concentrations used for the PCR

\begin{tabular}{lll}
\hline $\begin{array}{l}\text { Sample } \\
\text { no. }\end{array}$ & $\begin{array}{l}\text { Approximate dilutions } \\
\text { of DNA for } 50(\mu \mathrm{g} / \mu \mathrm{L})\end{array}$ & $\begin{array}{l}\text { Approximate dilutions } \\
\text { of DNA for } 100(\mu \mathrm{g} / \mu \mathrm{L})\end{array}$ \\
\hline 1 & $1: 34.6$ & $1: 17.3$ \\
2 & $1: 48.4$ & $1: 24.2$ \\
3 & $1: 65.1$ & $1: 32.5$ \\
4 & $1: 45.3$ & $1: 22.7$ \\
5 & $1: 37.5$ & $1: 18.8$ \\
6 & $1: 7$ & $1: 3.5$ \\
7 & $1: 74.1$ & $1: 37.1$ \\
8 & $1: 31.5$ & $1: 15.7$ \\
\hline \hline
\end{tabular}


of denaturation at $94{ }^{\circ} \mathrm{C}$ for $40 \mathrm{sec}$, second step of annealing according to temperature of primers (Table 3) for $40 \mathrm{sec}$ and $3^{\text {rd }}$ an extension step for $1 \mathrm{~min}$ at $72{ }^{\circ} \mathrm{C}$. The last step was followed by a final extension of $10 \mathrm{~min}$ at $72{ }^{\circ} \mathrm{C}$. Amplified products were electrophoresed with $6 \times$ loading dye on $1.5 \%$ agarose gel stained with ethidium bromide and subsequently visualized using the gel documentation system (GDS).

Table 3. Primers used for PCR

\begin{tabular}{lll}
\hline \hline $\begin{array}{l}\text { Name of } \\
\text { primer }\end{array}$ & Sequence of primer & $\begin{array}{l}\text { Temperature } \\
\left({ }^{\circ} \mathrm{C}\right)\end{array}$ \\
\hline OBP1 & GTTTCGCTCC & 34.3 \\
OPA2 & TGCCGAGCTG & 42 \\
OPA4 & AATCGGGCTG & 36 \\
OPA5 & AGGGGTCTTG & 33.5 \\
OPA7 & GAAACGGGTG & 34.1 \\
OPA9 & GGGTAACGCC & 38.8 \\
OPA19 & CAAACGTCGG & 35.1 \\
\hline \hline
\end{tabular}

\section{Results and Discussion}

Morphological parameters of guava plant. Different morphological parameters were studied in eight varieties of guava (Psidium guajava L.) during the research conducted. The parameters were studied qualitatively (leave shapes; Fig. 1-3) and collected by visualization and observation. All the descriptors were collected and studied by taking the descriptors following the procedure given by Kidaha et al. (2015) as a standard. The comparison (Table 4) was made and the scoring of parameters was done to study and understand easily the variation/similarities. In another (Table 5) scoring of morphological data with respect to the comparison table was made. For example, the presence of pubescence of the epical leaves, 1 number was given to those varieties which have no pubescence in their epical leaves and the 2 number was given to those varieties which have pubescence present in their apical leaves. Therefore, all the eight varieties have pubescence in their apical leaves.

Molecular characterisation of guava genotypes. $D N A$ analysis of eight guava varieties by $7 \mathrm{RAPD}$ primers. Seven RAPD primers were used for polymorphism in (Guava varieties.) initially. Such that OBP1, OPA2, OPA4, OPA5, OPA7, OPA9 and OPA19 were chosen for the RAPD PCR amplifications. Out of these 4 primers have given the polymorphic bands (Fig. 4-5). All these 4 primers showed dissimilar bands of base

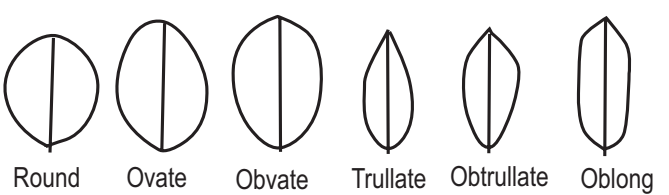

Fig. 1. Leaf shapes.
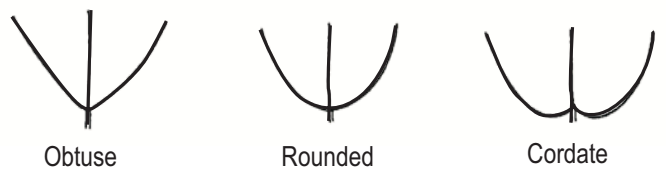

Fig. 2. Fully developed leaf shapes from base.
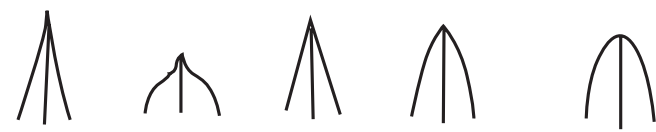

Attenuate

Apiculate

Acute

Obtuse

Rounded

Fig. 3. Fully developed leaf shape of leaf tips.

pair (bp) in different sizes. Others did not show any band, there are many possible reasons that the bands were not shown. The size of reproduceable and score able bands (Table 6) ranged differently in all primers and showed difference in 8 varieties of guava species. These results indicated that RAPD marker system used

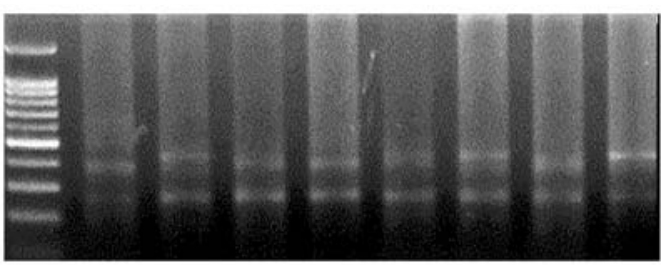

Fig. 4. Gel picture of OBP 1 primer with 100bp ladder

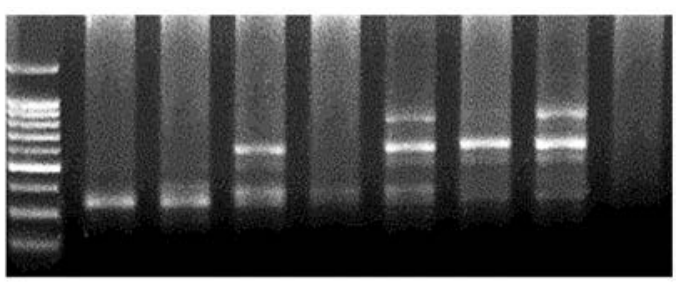

Fig. 5. Gel picture of OPA 2 primer with 100bp ladder 
Table 4. Comparison of different parameters

\begin{tabular}{|c|c|c|c|c|c|}
\hline Colour of apical leaves & $\begin{array}{l}\text { Yellowish green } \\
\text { with brown margins }\end{array}$ & $\begin{array}{l}\text { Light green with } \\
\text { brown margins }\end{array}$ & $\begin{array}{l}\text { Yellowish green with } \\
\text { light brown margins }\end{array}$ & $\begin{array}{l}\text { Light green with } \\
\text { light brown margins }\end{array}$ & $\begin{array}{l}\text { Greenish } \\
\text { brown }\end{array}$ \\
\hline $\begin{array}{l}\text { Pubescence on apical } \\
\text { leaves }\end{array}$ & Absent & Present & & & \\
\hline Leaf petiole colour & Yellowish green & Light green & Green & Reddish green & \\
\hline Colour of leaf vein & Yellowish green & Light green & Green & & \\
\hline Mature leaf colour & Light green & Green & Dark green & Maroon green & \\
\hline Leaf shape & Ovate & Obvate & Oblong & Round & \\
\hline $\begin{array}{l}\text { Leaf shape from base } \\
\text { of leaf }\end{array}$ & Obtuse & Round & Cordate & & \\
\hline $\begin{array}{l}\text { Leaf shape from tip } \\
\text { of leaf }\end{array}$ & Obtuse & Round & Acute & Apiculate & \\
\hline Leaf twisting & Absent & Little present & Present & & \\
\hline Branch colour & Light grey & Brownish grey & Dark grey & & \\
\hline Branching habit & Irregular & Semi erect & Erect & & \\
\hline
\end{tabular}

All the descriptors for morphological data are taken and studied by Kidaha et al. (2015). Some parameters are added more to understand variation in guava varieties, like brownish grey and semi erect habit of plant branch colour and branching habit, respectively.

Table 5. Morphological scored data

\begin{tabular}{lllllllll}
\hline \hline Morphological parameters & \multicolumn{7}{c}{ Name of varieties } \\
\cline { 2 - 8 } & RWGola & SBahar & SBBSurahi & Larkana & Kohati & SAmrod & MSWala & ABSurahi \\
\hline Colour of apical leaves & 4 & 1 & 3 & 3 & 3 & 5 & 2 & 2 \\
Pubescence on apical leaves & 2 & 2 & 2 & 2 & 2 & 2 & 2 & 2 \\
Leaf petiole colour & 1 & 3 & 3 & 3 & 4 & 4 & 3 & 1 \\
Color of leaf vein & 1 & 2 & 2 & 2 & 2 & 2 & 1 & 1 \\
Mature leaf colour & 4 & 4 & 4 & 4 & 2 & 4 & 1 & 3 \\
Leaf shape & 2 & 3 & 1 & 1 & 3 & 1 & 3 & 1 \\
Leaf shape form base of leaves & 1 & 2 & 2 & 2 & 3 & 1 & 1 & 2 \\
Leaf shape from tip of leaves & 1 & 1 & 2 & 1 & 1 & 1 & 1 & 2 \\
Leaf twisting & 3 & 2 & 1 & 2 & 1 & 3 & 2 & 1 \\
Branch colour & 2 & 2 & 1 & 2 & 3 & 3 & 3 & 3 \\
Branching habit & 1 & 1 & 1 & 1 & 3 & 1 & 3 & 3 \\
\hline \hline
\end{tabular}

in this study revealed a little range of genomic DNA diversity in guava (Psidium guajava L.) plant and its related varieties. Little variation is due to less number of plants or varieties available (Sharma et al., 2010).

In order to score the gel picture produced through the running of PCR product on the $1.5 \%$ agarose gel of different primers, the producible and scoreable bands of different base pair sizes were scored as 1 as presence of the band and the 0 as the absence of the respective band at respective base pair size in the gel picture.

DNA markers data based clustering of guava genotypes. In order to probe into the genetic diversity between different eight varieties of guava a reconstruction was carried out. The sequences and scoring of molecular marker were edited using NTedit and a neighbor joining tree was constructed by using NTSYSpc 2.1 Software (Rohlf, 2000).) The clustering tree of similarity (Fig. 6) showed that there was a clear image of the genetic diversity present in eight varieties of guava. The tree showed differentiation into different clades. The Kohati is sister to SBBSurahi and MSWala is sister to SAmrod. Through this tree we have found that there is no major genetic diversity in between the RWGola and Larkana varieties of guava. However, the ABSurahi seems to be the progenitors according to the results of these 7 primers used in these eight varieties of the guava.

Morphological parameters based clustering of guava genotypes. While studying the morphological diversity between eight varieties, a clustering tree of similarity 
Table 6. Bands scored data at different base pair (bp) of different primers

\begin{tabular}{|c|c|c|c|c|c|c|c|c|c|c|c|}
\hline Name of varieties & $\begin{array}{l}\text { OBP } \\
1 \mathrm{~A}\end{array}$ & $\begin{array}{l}\text { OBP } \\
1 \mathrm{~B}\end{array}$ & $\begin{array}{l}\text { OBP } \\
1 \mathrm{C}\end{array}$ & $\begin{array}{l}\text { OPA } \\
2 \mathrm{~A}\end{array}$ & $\begin{array}{l}\text { OPA } \\
2 \mathrm{~B}\end{array}$ & $\begin{array}{l}\text { OPA } \\
2 \mathrm{C}\end{array}$ & $\begin{array}{l}\text { OPA } \\
2 \mathrm{D}\end{array}$ & $\begin{array}{l}\text { OPA } \\
2 \mathrm{E}\end{array}$ & $\begin{array}{l}\text { OPA } \\
4 \mathrm{~A}\end{array}$ & $\begin{array}{l}\text { OPA } \\
4 \mathrm{~B}\end{array}$ & $\begin{array}{l}\text { OPA } \\
5 \mathrm{~A}\end{array}$ \\
\hline Rang wala gola & 1 & 1 & 0 & 1 & 0 & 0 & 0 & 0 & 0 & 0 & 1 \\
\hline Sadabahar & 1 & 1 & 1 & 1 & 1 & 0 & 0 & 0 & 0 & 0 & 1 \\
\hline $\begin{array}{l}\text { Sadabahar barhi } \\
\text { Surahi }\end{array}$ & 1 & 1 & 0 & 1 & 1 & 1 & 1 & 0 & 0 & 1 & 0 \\
\hline Larkana & 1 & 1 & 0 & 1 & 0 & 0 & 0 & 0 & 0 & 1 & 1 \\
\hline Kohati & 1 & 1 & 0 & 1 & 1 & 1 & 1 & 1 & 0 & 0 & 0 \\
\hline Special amrod & 1 & 1 & 1 & 1 & 0 & 1 & 1 & 0 & 1 & 1 & 0 \\
\hline Moti surahi wala & 1 & 1 & 0 & 1 & 0 & 1 & 1 & 1 & 1 & 1 & 0 \\
\hline Amrod barhi surahi & 1 & 0 & 1 & 0 & 0 & 0 & 0 & 0 & 1 & 1 & 0 \\
\hline
\end{tabular}

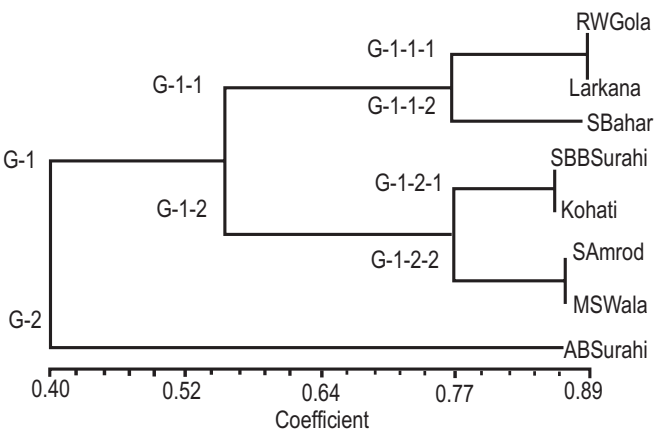

Fig. 6. DNA markers data based clustering of guava genotypes

was produced and a reconstruction was carried out. The qualitative readings were edited using NTedit and a neighbor joining tree was constructed by using NTSYSpc 2.1 software. The figure produced (Fig. 7) showed the clear morphological diversity present in eight varieties of guava. The tree showed differentiation into different clades. In this dendogram of morphological similarities, there were two main groups G-1 and G-2. The group G-1 leads toward two further groups G-1-1 and G-1-2, the group G-1-1 leads to two further groups G-1-1-1 and G-1-1-2 with respective varieties named as RWGola and SAmrod. The group G-1-2 leads to two groups G1-2-1 and G-1-2-2 in which the group G-1-2-1 leads to two varieties with no diversity named as SBahar and Larkana, while the group G-1-2-2 leads to the single variety SBBSurahi. The group G-2 splits into two groups G-2-1 and G-2-2, the group G-2-1 leads to G-2-1-1 and G-2-1-2 with Kohati and MSWala varieties of guava, respectively. The group G-2-2 leads to the ABSurahi variety.

In both dendograms there were no similar results about the diversity present in the both results. The

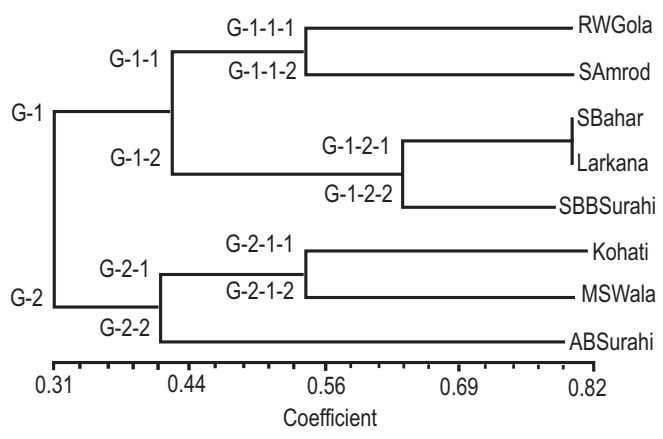

Fig. 7. Morphological parameters based clustering of guava genotypes

morphological study of parameters showed different tree of similarity in the eight varieties and the results of molecular markers showed different results. In both results the results of molecular markers were more authentic compared to the morphological results. There were many possibilities which can lead to the difference in the results of both dendograms and the growth of the plant of same varieties at the same field could be different in many ways. Usual causes of differences can be; effect of plant mineral nutrition, biotic stress and abiotic stress (Ahmad and Imtiaz, 2003). The molecular markers were more reliable because it takes generation to change the genetic makeup of the plant or any organism. Through these results, it was concluded that the morphological parameters were not so confirm as compared to the genetic parameters so that we can be able to describe any diversity or similarity in the eight varieties of guava.

\section{Conclusion}

In order to fullfil the requirements of the remarkable breeding programmes the massive knowledge about the progenies and germplasm characterisation is required. 
Characterisation of Pakistani gauva germplasm was done through the molecular markers and physiological descriptors in this research which has given the authenticated results through the molecular markers in comparison to the physiological descriptors. The selection of the plants for the improvement breeding of the guava could be easier in these eight varieties of Pakistani guava. The only genetical data could be followed for further research because the genetical data is more authenticated than the morphological data. There are many possible reasons for the morphological data showing dissimilarity from the genetical data i.e., the rain-fed conditions, sun light availability to leaves, nutrient availability/problem and disease problems etc.

Conflict of Interest. The authors declare no conflict of interest.

\section{References}

Ahmed, M., Qamar, I. 2004. Productive rehabilitation and use of salt-affected land through aforestation. (A Review). Science Vision, 9: 1-14.

Akbar, F., Rabbani, M.A., Masood, M.S., Shinwari, Z.K. 2011. Genetic diversity of sesame (Sesamum indicum L.) germplasm from Pakistan using Rapd markers. Pakistan Journal of Botany, 43: 2160.

Bakhat, J., Nazma, J., Shafi, M. 2012. Appraisal of genetic diversity of different peaches cultivars and genotypes through RAPD primers. Pakistan Journal of Botany, 44: 1527-1532.

Doyle, J.J., Doyle, J.L. 1990. Isolation of plant DNA from fresh tissue. Focus, 12: 13-15.

Elmeer, K., Almalki, A. 2011. DNA fingerprinting of Prosopis cineraria L. and Prosopis juliflora L. using ISSR and RAPD techniques. American Journal of Plant Sciences, 2: 527-534.

Enjalbert, J., Goldringer, I., Paillard, S., Brabant, P. 1999. Molecular markers to study genetic drift and selection in wheat population. Journal of Experimental Botany, 50: 282-290.
Jaiswal, U., Jaiswal, V.S. 2005. Biotechnology of fruit and nut crops. Biotechnology in Agricultural Series, 29. pp. 394-401, Cambridge: CAB Publishers. UK.

Kidaha, L.M., Alakonya, A.E., Nyende, A.B. 2015. Morphological characters of guava landraces in western and coastal Kenya. American Journal of Experimental Agriculture, 9: 1-11.

Luanda, G.M., Ana, M.S., Jose, T.F. 2006. Freeze drying characteristics of tropical fruits. Drying Technology An International Journal, 24: 457-463.

Malabadi, R.B., Hills, P.N., Staden, J.V. 2006. RAPD assessment of clonal identity of somatic seedlings derived from vegetative shoot apices of mature Pinus patula tree. South African Journal of Botany, 72: 181-183.

Mumford, J.M., Norton, G.A., 1984. Economics of decision making in pest management. Annual Review of Entomology, 29: 157-174.

Prakash, S., Staden, J.V. 2008. Genetic variability and species identification within Encephalatos using RAPD markers. South African Journal of Botany, 74: 735-739.

Rahman, M., Begum, K., Begum, M., Faruque, C.A.A. 2003. Correlation and path analysis in guava. Bangladesh Journal of Agricultural Research, 28: 93-98.

Rohlf, F.J. 2000. NTSYS-PC: Numerical Taxonomy and Multivariate Analysis System, Version 2.2 Exeter Software, Exerter Publishing, Setauket, New York, USA.

Sharma, A., Sehrawat, S.K., Singhrot, R.S., Tele, A. 2010. Morphological and chemical characterisation of Psidium species. Notulae Botanicae Horti Agrobotanici, 38: 28-32.

Wangsomnuk, P.P., Khampa, S., Wangsomnuk, P., Jogloy, S., Mornkham, T., Ruttawat, B., Patanothai, A., Fu, Y.B. 2011. Genetic diversity of worldwide Jerusalem artichoke (Helianthus tuberosus) germplasm as revealed by RAPD markers. Genetic and Molecular Research, 10: 4012-4025. 